\title{
Green Roof Performance Towards Good Habitat for Butterflies in the Compact City
}

\author{
Lee-Hsueh Lee ${ }^{1} \&$ Jun-Cheng Lin ${ }^{1}$ \\ ${ }^{1}$ Department of Landscape Architecture, Chung Hua University, Hsinchu, Taiwan \\ Correspondence: Lee-Hsueh Lee, Department of Landscape Architecture, Chung Hua University, 707, Sec.2, \\ WuFu Rd., Hsinchu, Taiwan, R.O.C. Tel: 886-935-624-046. E-mail: 1slee@chu.edu.tw
}

Received: February 20, 2015 Accepted: March 9, 2015 Online Published: March 14, 2015

doi:10.5539/ijb.v7n2p103 URL: http://dx.doi.org/10.5539/ijb.v7n2p103

\begin{abstract}
Urban ecology is threatened by habitat loss and fragmentation due to increasing urbanization. Green roofs may act as habitats to compensate for loss of green space at the ground level. Here, we assessed greening variables of 11 green roofs for butterflies in Taipei City. Butterfly number, species, and richness on green roofs were lower than parks, but some less common species were observed on green roofs. The nectar plant area, number of nectar plant species and age of green roof were the main positive effectors of butterfly number. The height above ground of green roof had not impact on butterfly survival; supposed high rise buildings are spreading out over city that would be a potential good habitat for butterflies on skyscape. However, since the scale of green roofs was small in Taipei, we adopted a habitat suitability index (HSI) method to determine optimal value of selected greening variables to attract more butterfly number on green roofs. HSI curves' findings suggested that achieving a nectar plant area of more than $25 \mathrm{~m}^{2}$ and not less than 10 nectar plant species would greatly benefit butterfly number; meanwhile, the age of green roof was higher than 38 months, butterfly number is expected to increase rapidly. We confirmed that carefully design green roof could play a good habitat for butterflies in Taipei city.
\end{abstract}

Keywords: habitat suitability index curve, green roofs, nectar plants, urbanization, greening approach

\section{Introduction}

The increase of human populations in city centers and urban sprawl has eliminated or severely restricted green space and threatens habitats. Since large amounts of land area are covered by various kinds of buildings makes the urban green space area at ground level is limited, many countries have begun to consider the green roof as an important habitat for wildlife in the city (Oberndorfer et al., 2007). Green roofs in urban centers provide other benefits such as mitigation of urban heat islands, reduced energy use, reduced air pollution, enhanced storm water management, and the creation of natural habitats for animals and plants (Carter \& Fowler, 2008; Clark, Adriaens, \& Talbot, 2008; USGSA, 2013).

Green roofs in large cities have high potential as habitat for species negatively impacted by land-use changes (Brenneisen, 2006). Although green roofs support a lower abundance of invertebrate than nearby urban green space (Brenneisen, 2006; Gedge \& Kadas, 2005; Kadas, 2006; Snep, WallisDeVries, \& Opdam, 2011), green roofs can be designed to mitigate habitat loss for insects and wildlife in urban areas ( Colla, Willis,, \& Packer, 2009; Ksiazek, Fant, \& Skogen, 2012; MacIvor \& Lundholm 2011; Tonietto, Fant, Ascher, Ellis, \& Larkin, 2011).

Butterflies are highly appreciated by the public because of their beautiful appearance and daytime activities, which can be easily observed. The survival of butterflies is affected by various factors of urbanization (Dennis \& Hardy 2001; Wood \& Pullin, 2002). Urban development, habitat loss, and fragmentation have a negative impact on butterfly species distributions, species richness, and Shannon diversity (Blair \& Launer, 1997; Di Mauro, Dietz, \& Rockwood, 2007). Blair \& Launer (1997) asserted that some butterfly species can survive in urban areas that have suitable habitats. And butterfly diversity in urban areas can be preserved by constructing suitable habitats in these areas (Chikamatsu, Natuhara, Mizutani, \& Nakamura,2002; Collier, Mackay, Benkendorff, Austin, \& Carthew, 2006; Smallidge \& Leopold, 1997; Wood \& Pullin, 2002).

We was sensible to deliberately determined six greening variables had effect on butterflies survival on green roof, which include total greening area, nectar plant area, number of nectar plant species, age of green roof, height above ground and surrounding green space ratio. Insects may be more attracted to suitable green roof vegetation 
due to the provision of appropriate food sources or pollen resources (Coffman \& Waite, 2010; Everaars, Strohbach, Gruber, \& Dormann, 2011; Gedge \&d Kadas, 2005; Lundholm 2006), meanwhile nectar plants are the major plants that attract butterflies in metropolitan areas (Sharp, Parks, \& Ehrlich, 1974). Insect survival on green roof was influenced by vegetal structures (Coffman \& Waite, 2010; Madre, Vergnes, Machon, \& Clergeau, 2013), which can offer suitable habitats for the foraging or nesting of a variety of insects (Colla et al., 2009; Everaars et al., 2011; Ksiazek et al., 2012).

The number of arthropod species was positively correlated with living vegetation cover; but was not significantly correlated with the distance of green roof from the ground (Schindler, Griffith, \& Jones, 2011), that may higher sun exposure between buildings provide a good environment for insects (Everaars et al., 2011). Thus, carefully designed green roofs have the potential to be used to support more species in urban area (Bates, Sadler, \& Mackay, 2013; Molles, 2005; Smallidge \& Leopold 1997).

The presence of wild species was influenced by geographic location (Coffman \& Waite, 2011). Kadlec, Benes, Jarosik, and Konvicka (2008) asserted that fragmentary habitats could support small butterfly survival. Butterflies move from patch to patch, their dispersal range is typically no more than $2 \mathrm{~km}$ (Maes \& Bonte, 2006), and $1 \mathrm{~km}$ has been described as an appropriate "stepping stone" distance between butterfly habitats, green roofs can act as stepping stones and refuges for butterflies and insects in urban (Dramstad, Olson, \& Forman, 1996; Snep et al., 2011).

Taipei city is the capital of Taiwan, has a population over three million people within a total area of $272 \mathrm{~km}^{2}$, with population density nearly 10,000 people $/ \mathrm{km}^{2}$ and is the seventh most populous city in the world. The population density is even more than 27,000 people $/ \mathrm{km}^{2}$ in city center. Parks and green space areas are less than $5 \%$ of total area (Taipei City Government, 2014); it would be difficult to increase green space on the ground level. In Taipei City center area, there were more than 110 types of butterflies identified in 1936, 69 from 1960 to 1970, and 50 in 2008 (Zhou, 2009); however, many butterflies have disappeared due to habitat loss from urbanization (Hiura, 1973; Jiang, 2012; Zhou, 2009). Therefore, green roofs may mitigate habitat loss in this urban area (Colla et al, 2007), green roofs represent bioengineering (Matteson \& Langellotto, 2011) and carefully design green roof can offer suitable habitat for butterflies.

In our study, we used an interdisciplinary approach that combined several methods for answer the following questions: (1) we would compare green roofs with parks to verify that green roof is a potential habitat for butterflies in Taipei city, (2) tested for the critical greening variables of green roof affect butterfly survival, (3) determine the optimal value of selected greening variables could attracted more butterfly number on green roof, (4) made the suggestion of construct sufficient habitats on green roof and planning green roof the location for butterflies in compact city.

\section{Materials and Methods}

\subsection{Study Sites and Greening Variables Survey}

We selected 11 public buildings were located in Taipei city, Taiwan (Figure 1), and carry out the greening variables survey from August 2011 to May 2012; which were set up extensive green roofs that were under maintenance, with planting mediums at depths below $20 \mathrm{~cm}$.

For each green roof, we measured 7 greening variables, i.e. site area of roof, greening area, nectar plant area, number of nectar plant species, height above ground, age of green roof, and surrounding green space ratio.

Greening area was figured on total greening area of roof. Nectar plant was defined the plant attract butterflies; height above ground was estimated the height from ground level to green roof location; age of green roof was calculated the period from green roof was established to investigation timing. Finally, we calculated the surrounding green space ratio that was the proportion of all area of parks and green space to all land area within a 1000-m radius of green roof, the park and green space was according to land-use regulations of Taipei urban planning, and verified by 2011 aerial photograph.

We surveyed these greening variables on each site twice per month from August 2011 to May 2012, total 20 times. All 11 buildings were constructed more than 20 years ago; roof area was from 142 to $610 \mathrm{~m}^{2}$, the entire green roof area ranged from 95 to $590 \mathrm{~m}^{2}$. The height above ground of green roof was form 7 to $34 \mathrm{~m}$. The ages of the green roofs ranged from 13 to 46 months old from green roof was established to August 2011. The surrounding green space ratio was from $3.84 \%$ to $50.68 \%$.

The plants and nectar plants were identified by the Catalogue of Life in Taiwan (TaiBNET, 2011), the Taiwan Biodiversity Information Facility (TAIBIF, 2011), the Taiwan Flowers and Plants Illustrated Handbook (Xue, 2003) and Taiwan Butterfly Host and Nectar Plant Illustrated Handbook (Lin, 2008). During the study period, we recorded 34 butterfly nectar plants species belonging to 16 families. Statistics for all nectar plants from 11 
green roofs were calculated; these green roofs contained primarily Asteraceae, Brassicaceae, Rubiaceae and Verbenaceae family plants; the most five common nectar plant species were Belamcanda chinensis (Belamcanda family), Begonia semperflorens Link. \& Otto (Begoniaceae family), Youngia japonica (L.) DC. (Youngia family), Oxalis corymbosa DC. (Oxalis family), and Bidens pilosa L. var. radiata (Bidens family).

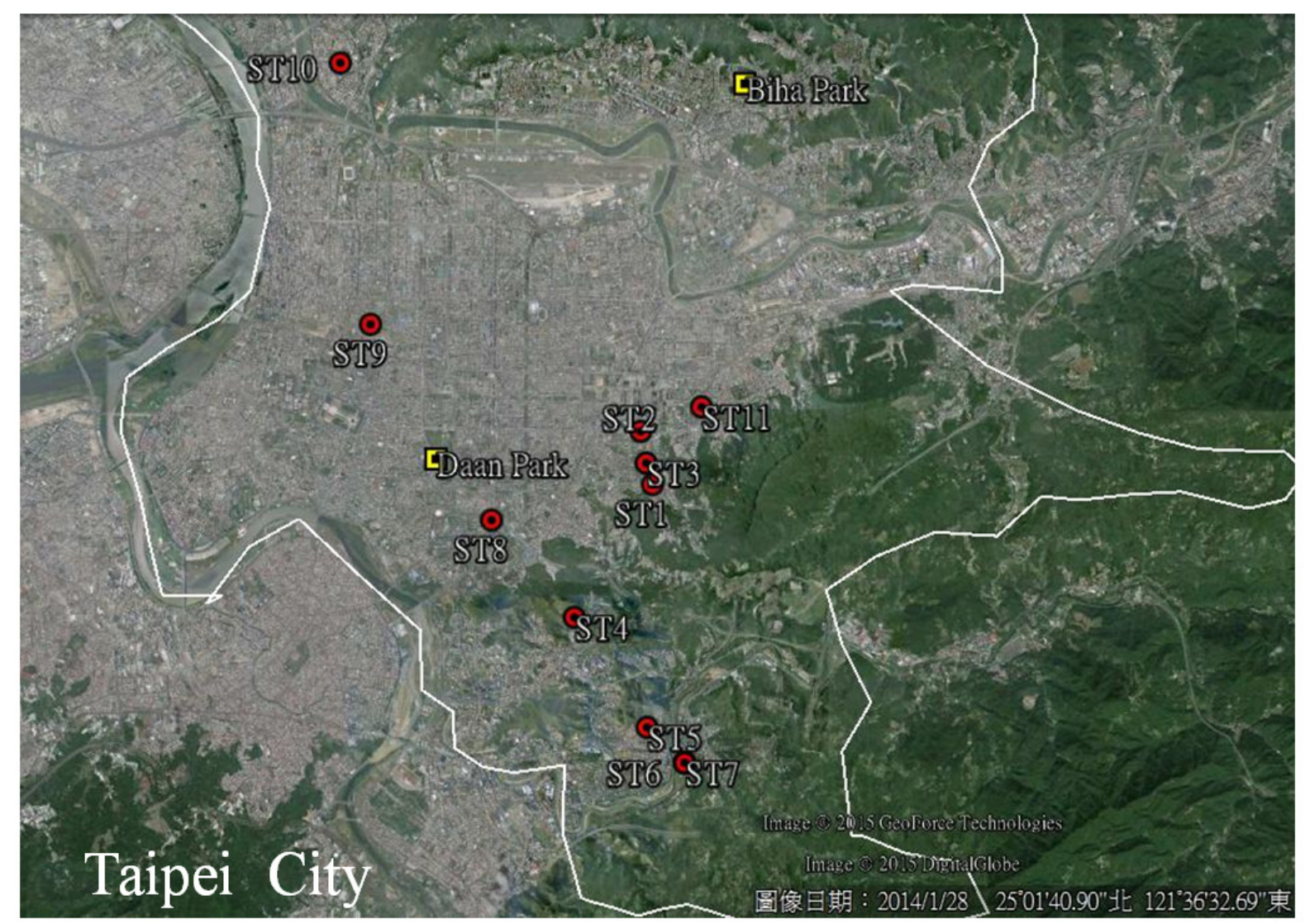

\begin{tabular}{|c|c|c|c|}
\hline ST1 & $\begin{array}{l}\text { ChengDe Junior High School } \\
25^{\circ} 01^{\prime} 32.68^{\prime \prime N} 121^{\circ} 34^{\prime} 7.41^{\prime \prime} \mathrm{E}\end{array}$ & ST2 & $\begin{array}{l}\text { Xinyi District office } \\
25^{\circ} 01^{\prime} 59.71^{\prime \prime} \mathrm{N} 121^{\circ} 34^{\prime} 1.03^{\prime \prime} \mathrm{E}\end{array}$ \\
\hline ST3 & $\begin{array}{l}\text { Xinyi Junior High School } \\
25^{\circ} 01^{\prime} 43.56^{\prime \prime N ~} 121^{\circ} 34^{\prime} 3.95^{\prime \prime} \mathrm{E}\end{array}$ & ST4 & $\begin{array}{l}\text { Department of Civil Servant } \\
\text { Development Building } \\
25^{\circ} 0^{\prime} 11.89^{\prime \prime N ~} 121^{\circ} 33^{\prime} 39.52^{\prime \prime} \mathrm{E}\end{array}$ \\
\hline ST5 & $\begin{array}{l}\text { Wenshan School of Special Education } \\
24^{\circ} 59^{\prime} 29.53^{\prime \prime} \mathrm{N} 121^{\circ} 34^{\prime} 4.12^{\prime \prime} \mathrm{E}\end{array}$ & ST6 & $\begin{array}{l}\text { North Site ChengGhi University } \\
24^{\circ} 59^{\prime} 11.28^{\prime \prime N} 121^{\circ} 34^{\prime} 24.92^{\prime \prime} \mathrm{E}\end{array}$ \\
\hline ST7 & $\begin{array}{l}\text { South Site, ChengGhi University } \\
24^{\circ} 59^{\prime} 11.28^{\prime \prime N} 121^{\circ} 34^{\prime} 24.92^{\prime \prime} \mathrm{E}\end{array}$ & ST8 & $\begin{array}{l}\text { Tsai Lecture Hall, Taiwan University } \\
25^{\circ} 01^{\prime} 14.85^{\prime \prime} \mathrm{N} 121^{\circ} 32^{\prime} 37.12^{\prime \prime} \mathrm{E}\end{array}$ \\
\hline ST9 & $\begin{array}{l}\text { LinSen community centre } \\
25^{\circ} 02^{\prime} 54.52^{\prime \prime} \mathrm{N} 121^{\circ} 31^{\prime} 29.52^{\prime \prime} \mathrm{E}\end{array}$ & ST10 & $\begin{array}{l}\text { BaiLing Elementary School } \\
25^{\circ} 05^{\prime} 7.38^{\prime \prime N} 121^{\circ} 31^{\prime} 13.09^{\prime \prime} \mathrm{E}\end{array}$ \\
\hline TT11 & $\begin{array}{l}\text { Chung Shih community centre } \\
25^{\circ} 05^{\circ} 05.45^{\prime} \mathrm{N} 121^{\circ} 32^{\prime} 16.95^{\prime} \mathrm{E}\end{array}$ & & \\
\hline
\end{tabular}

Daan Park $25^{\circ} 1^{\prime} 46^{\prime \prime} \mathrm{N} 121^{\circ} 32^{\prime} 6^{\prime \prime} \mathrm{E}$.

Biha Park 254'56"N $121^{\circ} 35^{\prime} 0^{\prime \prime} \mathrm{E}$

Figure 1. The map shows the research sites location, included 11 green roofs and two parks in Taipei city 
Table 1. Description of 11 green roofs and parks

\begin{tabular}{|c|c|c|c|c|c|c|c|}
\hline $\begin{array}{c}\text { Green } \\
\text { roof }\end{array}$ & $\begin{array}{c}\text { roof area }{ }^{a} \\
\left(\mathrm{~m}^{2}\right)\end{array}$ & $\begin{array}{l}\text { greening } \\
\text { area }^{b}\left(\mathrm{~m}^{2}\right)\end{array}$ & $\begin{array}{l}\text { height } \\
\text { above } \\
\text { ground }^{\mathrm{c}} \\
(\mathrm{m})\end{array}$ & $\begin{array}{c}\text { nectar plant } \\
\text { area }^{\mathrm{d}} \\
\left(\mathrm{m}^{2}\right)\end{array}$ & $\begin{array}{c}\text { number of } \\
\text { nectar } \\
\text { plant }^{\mathrm{e}} \\
\text { species }\end{array}$ & $\begin{array}{c}\text { age of } \\
\text { green roof } \\
\mathrm{f} \text { (months) }\end{array}$ & $\begin{array}{l}\text { surrounding } \\
\text { green space } \\
\text { ratio }^{\mathrm{g}}(\%)\end{array}$ \\
\hline ST1 & 180 & 124 & 3 & 15.20 & 4 & 21 & 18.30 \\
\hline ST2 & 600 & 410 & 11 & 29.73 & 16 & 46 & 8.92 \\
\hline ST3 & 637 & 590 & 3 & 13.18 & 3 & 41 & 20.33 \\
\hline ST4 & 234 & 234 & 2 & 5.20 & 8 & 29 & 50.68 \\
\hline ST5 & 188 & 93 & 6 & 1.90 & 1 & 17 & 30.19 \\
\hline S56 & 160 & 105 & 6 & 16.56 & 6 & 18 & 40.53 \\
\hline ST7 & 152 & 127 & 7 & 10.70 & 8 & 18 & 40.53 \\
\hline ST8 & 610 & 330 & 3 & 8.30 & 4 & 13 & 7.05 \\
\hline ST9 & 142 & 120 & 4 & 7.75 & 5 & 18 & 3.84 \\
\hline ST10 & 214 & 135 & 3 & 8.90 & 6 & 30 & 5.67 \\
\hline ST11 & 250 & 192 & 3 & 41.10 & 13 & 45 & 45.80 \\
\hline Park & area (ha) & $\begin{array}{c}\text { greening } \\
\text { area }^{b}\left(\mathrm{~m}^{2}\right)\end{array}$ & $\begin{array}{l}\text { height } \\
\text { above } \\
\text { ground } \\
(\mathrm{m})\end{array}$ & $\begin{array}{c}\text { nectar plant } \\
\text { area }^{\mathrm{d}} \\
\left(\mathrm{m}^{2}\right)\end{array}$ & $\begin{array}{c}\text { number of } \\
\text { nectar } \\
\text { plant }^{\mathrm{e}} \\
\text { species }\end{array}$ & $\begin{array}{c}\text { age of } \\
\text { park (to } \\
2011 \text { ) } \\
\text { (year) }\end{array}$ & $\begin{array}{l}\text { surrounding } \\
\text { green space } \\
\text { ratio }{ }^{\mathrm{g}}(\%)\end{array}$ \\
\hline $\begin{array}{l}\text { Daan } \\
\text { Park }\end{array}$ & 26 & - & - & - & 20 & 18 & - \\
\hline $\begin{array}{l}\text { Bihu } \\
\text { Park }\end{array}$ & 13 & - & - & - & 45 & 25 & - \\
\hline
\end{tabular}

(a) the whole roof area.

(b) total greening area on roof.

(c) estimated the height from ground level to green roof location.

(d) total area of butterfly-attractive plants.

(e) total butterfly-attractive plant species.

(f) total months form green roof was establish to August, 2011.

(g) the proportion of all area of parks and green space to all land area within a 1000-m radius of green roof.

\subsection{Butterfly Sampling}

Due to the area of 11 green roofs were small, butterfly sampling was performed by the main method of observation, and the net-capture method was subordinate. Each site was surveyed from 9:00 to 11:00 and 14:00 to 16:00 at each survey time. Survey period was from August 2011 to May 2012, and twice per month, total 20 times.

We recorded 514 butterflies belonging to 5 families (12 species) during the investigation period on 11 green roofs. The most frequent species were Zizeeria maha okinawana (Zizeeria family; Matsumura, 1929; 69.8\% at 11 sites), followed by Pieris canidia (Pieris family; Linnaeus, $1768 ; 21.8 \%$ at 10 sites). The remaining 10 species, observed at lower frequencies, were Abraximorpha davidii ermasis (Abraximorpha family; ermasis Fruhstorfer, 1914), Catochrysops panormus exiguus (Catochrysops family;Distant, 1886), Danaus genutia (Danaus family; Cramer, 1779), Eurema blanda arsakia (Eurema family; Fruhstorfer, 1910), Graphium sarpedon connecten (Graphium family; Fruhstorfer, 1906), Hebomoia glaucippe formosana (Hebomoia family; formosana Fruhstorfer, 1908), Jamides bochus formosanus (Jamides family; formosana Fruhstorfer, 1908), Tirumala limniace (Tirumala family; Fruhstorfer, 1910), Vanessa indica (Vanessa family; Herbst, 1794), and Ypthima multistriata (Ypthima family; Butler, 1883). 


\subsection{Data analysis methods}

We used correlation analysis to test the greening variables (i.e., site area of roof, greening area, nectar plant area, number of nectar plant species, height above ground, age of green roof, and surrounding green space ratio) with the distribution of butterfly number, and the results would used to determine the significant impact of the greening variables on butterfly number.

HSI is based on hypothesized species-habitat relationships rather than statements of proven cause and effect relationships, which was employed to develop optimal habitat environment level of a certain habitat factor for that given species (Fish and wildlife Service, 1981; Schamberger \& O'neil, 1986). HSI curve was plotted by the $\mathrm{x}$-axis is a habitat variable and the $\mathrm{y}$-axis is a suitability score with 1 being optimum habitat and 0 being least suitable habitat. Below that hypothetical plots for given species where the curves describe suitability of habitat variables for that species existence. We utilized the normalized butterfly number as vertical axis and the individual selected greening variable as the horizontal axis, and then drew the envelope, that was the HSI for butterfly and greening variable. Then we could use the HSI curve to determine the optimal level of greening variables for butterflies on green roof.

\section{Results}

\subsection{Compared of Butterflies of Green Roofs and Park}

To show the green roof was a potential habitat for butterflies, we processed to compare butterflies species, number, species richness and Shannon-Wiener diversity index of 11 green roofs and Zhou (2009) and Jiang (2012) research finding.

Zhou (2009) research finding of the change of butterfly fauna at Daan Park, which location in Taipei city center, with area is 26 ha. 50 species belong to 7 families total 3141 butterflies were recorded from July 2008 to June 2009. The most frequent species was Pieris spp. (41.1\%; Pieridae family) and Zizeeria maha okinawaana (23.5\%; Zizeeria family; Matsumura, 1929).

Jiang (2012) research finding of butterfly fauna at Bihu Park, which located in the end of WuZhi mountain chain in Taipei city suburban; and with an 8 ha lake, total area is 13 ha. 109 species belong to 5 families total 8,882 butterflies were recorded from March 2011 to February 2012. The most frequent species was Pieris spp. (20.5\%; Pieridae family), Jamides spp.(9.9\%; Lycaenidae family), and Zizeeria maha okinawaana (8.5\%; Zizeeria family; Matsumura, 1929).

Both Zizeeria maha okinawana and Pieris canidia were dominant species at green roofs and parks. We also observed these butterflies species were nectar-based on green roofs, that was similar to Zhou's findings. There were fewer butterflies visiting green roofs than park $(\mathrm{p}=0.000)$. Butterflies species richness was significant different between green roof and park $(\mathrm{p}=0.019)$; but there was not a significant different between Shannon-Wiener diversity index at green roof and park.

\subsection{Dominant Influence of Greening Variables on Butterflies}

We performed correlation analysis using the 7 greening variables versus butterfly number to assess the relationships between greening variables and butterfly. The butterfly number was significantly correlated with the nectar plant area $(\mathrm{r}=0.825, p=0.003)$, number of nectar plant species $(\mathrm{r}=0.804, p=0.002)$, and age of green roof $(\mathrm{r}=0.895, p=0.000)$; all of these were positive correlations. No significant correlation was observed between butterfly number and site area of roof, greening area, height above ground, and surrounding green space ratio. Meanwhile, due to the butterflies species was very low, which was negligible in the step of correlation analysis.

\subsection{Habitat Suitability Index Curve of Greening Variables for Butterflies}

Our research main objectives was to determine the optimal value of greening variables, which was estimated by HSI method, and the results could be used to created a suitable habitat attract more butterflies.

When establishing HSI curve, the properties of greening variables should be determined, first. The correlation analysis results showed that nectar plant area, number of nectar plant species, and age of green roof were significant correlation with butterfly number, which were further described using the HSI method. Based on the HSI concept, we utilized the value of normalized butterfly number on the vertical axis and the values of individual greening variable on the horizontal axis; we then established an envelope based on the scatter plots of normalized butterfly number and of a particular greening variable, i.e., HSI curve for butterfly number and nectar plant area, number of nectar plant species and age of green roof, as shown in Figures 2-4. As shown in Figure 2, the nectar plant area rose with increasing butterfly number. When the nectar plant area was about $25 \mathrm{~m}^{2}$, there were many butterflies; after the increased trend become slowly. Therefore, we determined the optimal 
value of nectar plant area for butterflies on green roofs was not less than $25 \mathrm{~m}^{2}$. When the number of nectar plant species was about 10, there were many butterflies, the optimal value of number of nectar plant species for butterflies on green roofs was not less than 10 (Figure 3). Butterfly number continue to show an upward tendency from the green roof was established to nearly 38 months, after the trend become stability; and at this time, there were many butterflies. We believed that attracted more butterflies on green roof, which optimal value of age of green roof was not less than 38 months (Figure 4).

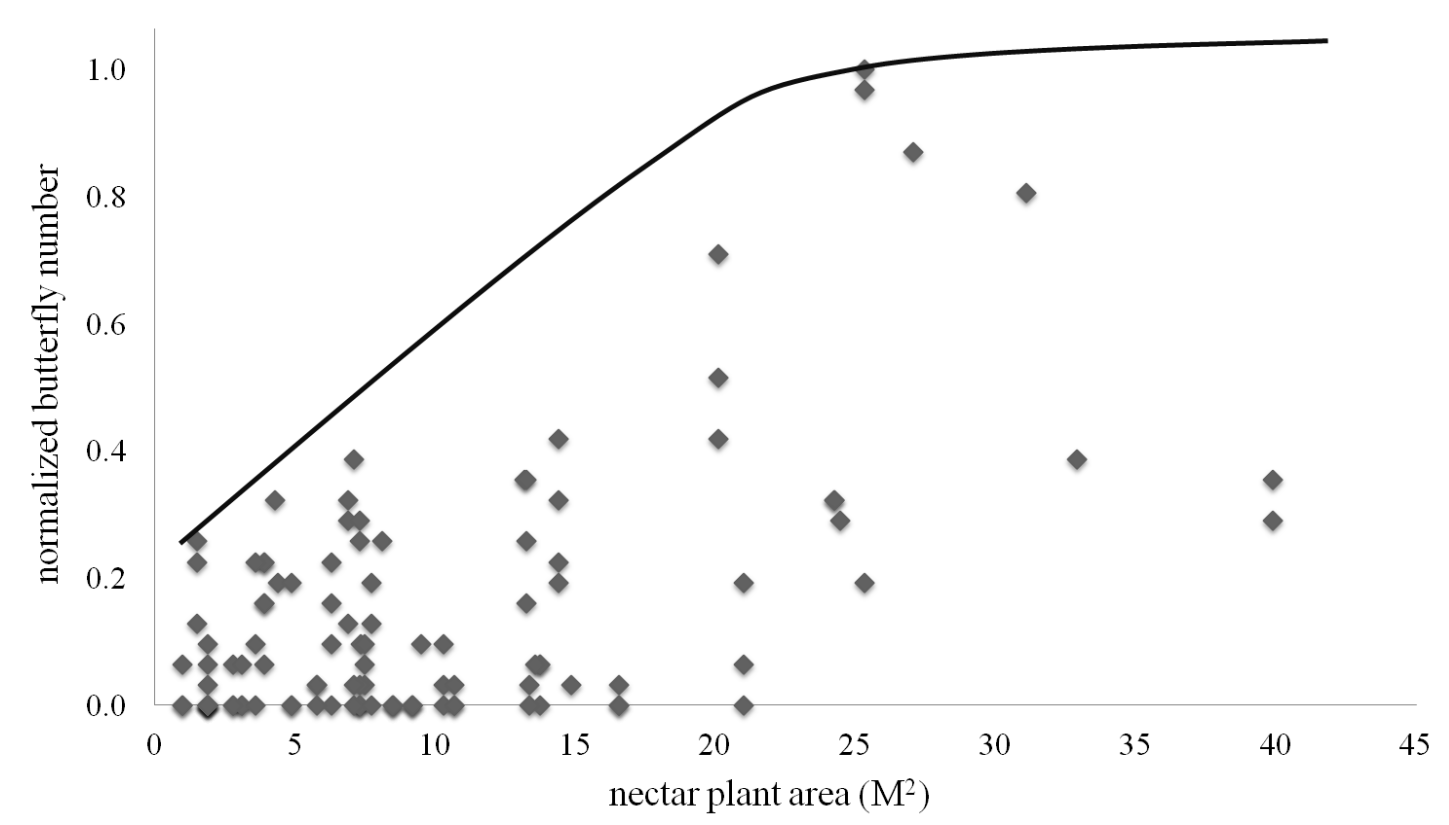

Figure 2. HSI curve for normalized butterfly number versus the nectar plant area. The curve used to determine the effect of nectar plant area on butterfly number. Nectar plant area was below $25 \mathrm{~m}^{2}$, butterfly number has a fast growth trend; once nectar plant area was over $25 \mathrm{~m}^{2}$, and the growth trend of butterfly number became stability

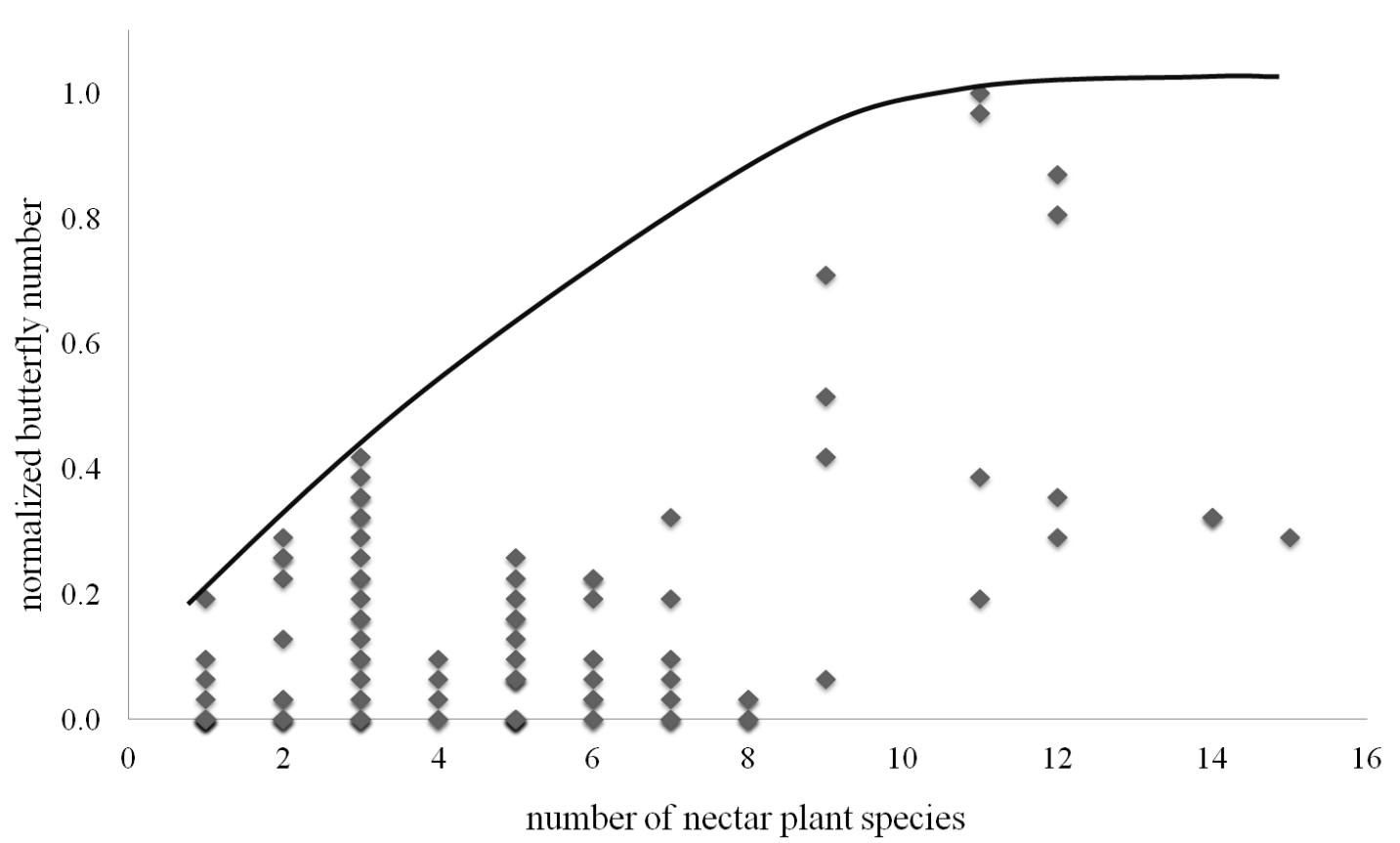

Figure 3. HSI curve for normalized butterfly number versus number of nectar plant species. Effect of the number of nectar plant species on butterfly number was determined by the curve. When the number of nectar plant species was less than 10, growth in butterfly number was increasing; after the growth trend of butterfly number was slower 


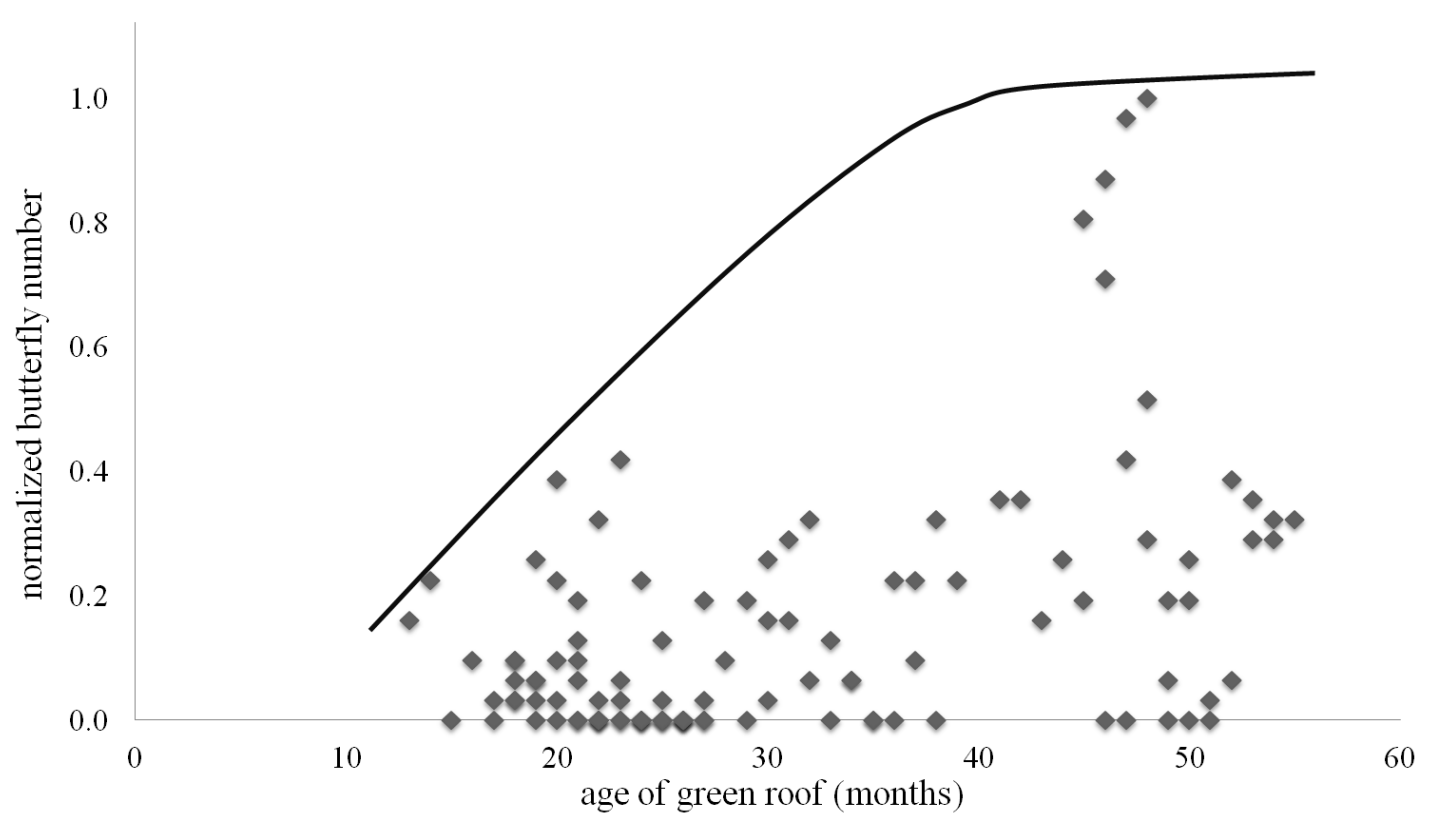

Figure 4. HSI curve for normalized butterfly number versus age of green roof. That used to determine the effect of green roof age on butterfly number. If green roof was established more than 38 months, butterfly number continued to show an upward tendency, after the growth trend became stability

\section{Discussion and Conclusions}

Butterflies were present on green roofs in Taipei city but were represented by fewer species and individuals than in parks. Few less common species were observed on green roof, although which support a lower abundance of bees than nearby urban park (Brenneisen, 2006; Gedge \& Kadas, 2005; Kadas, 2006; Snep et al., 2011).

In our research findings demonstrated that butterfly number were strongly influenced by nectar plant area and number of nectar plant species, which suggested that carefully design of green roofs would attract more butterflies (Bates et al., 2013; Coffman \& Waite ,2010; Collinge, Prudic, \& Oliver, 2003; Everaars et al., 2011; Feltwell, 1993; Lundholm, 2006; Molles, 2005; Saarinen, Valtonen, Jantunen, \&Saarnio, 2005; Vickery, 1995; Wood \& Samways, 1991). Meanwhile, butterfly number increased with the established time of green roof went on. Schrader \& Böning (2006) asserted that older green roofs had more stable environments for insects.

There are no significant correlations between butterfly number and height above ground of green roof (Snep et al., 2011). Sunlight is one of the major factors limiting butterfly diversity on the rooftops of heavily urbanized areas (Matteson \& Langellotto, 2010). That implied high-rise buildings are prevalent in large cities and can become good habitats for butterflies. Butterfly number and surrounding green space ratio of green roof was also no significant correlations. Madre et al. (2013) found the surrounding environment exhibited minor influences on arthropods survival. Moreover, the green space was very limited on ground level in Taipei city and the surrounding green space ratio of selected green roofs in our research was less than the research of Snep et al. (2011); that may be possible to cause no significant correlations between butterfly number and surrounding green space ratio.

In Taipei City, there are over 230,000 buildings, the average building area is less than $800 \mathrm{~m}^{2}$ (Taipei City Government, 2013), that could offer greening area was small. Green roofs are thought to function as novel habitat islands in urban settings, providing resources for butterflies (Fernandez-Canero \& Gonzalez-Redondo, 2010; Tonietto et al., 2011). We are sure the carefully designed green roofs had the better support potential for insect survival (Bates et al., 2013; Coffman \& Waite,2010; Davies, Simcock, \& Toft, 2010; Everaars et al., 2011; Gedge \& Kadas, 2005; Lundholm, 2006; Tonietto et al., 2011); the establishment of green roofs is critical to reducing habitat loss. Due to the habitat suitability index (HSI) method was being used to determine the greening variables appropriate condition for butterfly survival; we adopted HSI method to determine the optimal value of selected greening variables and confirm that with a small scale green roof, one can create a good habitat for butterflies in urban area. Our suggestions, for attract more butterflies, we must plant nectar plant area more than 
$25 \mathrm{~m}^{2}$ and at least 11 species of nectar plant species on green roof; which greening approach was suitable for the compact city of Taipei.

The dominant species appeared by an overwhelming majority on green roofs, but a few of less common butterfly species were observed. Suitable planting of green roofs may support more species (Bates et al., 2013; Everaars et al., 2011), and the diversity of blooming plants could increase insects diversity (Tonietto et al., 2011). Due to few butterfly species were observed, our research findings were useful to attract more butterfly number on green roofs. Clearly there is some extra restriction of our research. Such is the influence of some variables that it can promote number of butterfly species on green roof that must be explored. In the face of climate change impacts on urban areas, our research approach and methodology could easily be applied and modified to test the ecological benefit of green roof.

\section{References}

Bates, A. J., Sadler, J. P., \& Mackay, R. (2013). Vegetation development over four years on two green roofs in the UK. Urban Forestry \& Urban Greening, 12(1), 98-108. http://dx.doi.org/10.1016/j.ufug.2012.12.003

Blair, R. B., \& Launer, A. E. (1997). Butterfly diversity and human land use: Species assemblages along an urban grandient. Biological Conservation, 80(1), 113-125. http://dx.doi.org/10.1016/S0006-3207(96)00056-0

Brenneisen, S. (2006). Space for urban wildlife: designing green roofs as habitats in Switzerland. Urban Habitats, 4(1), 27-36.

Carter, T., \& Fowler, L. (2008). Establishing green roof infrastructure through environmental policy instruments. Environmental Management, 42(1), 151-164. http://dx.doi.org/10.1007/s00267-008-9095-5

Chikamatsu, M., Natuhara, Y., Mizutani, Y., \& Nakamura, A. (2002). Effect of artificial gaps on the butterfly assemblage in urban woods. Journal of the Japanese Society of Revegetation Technology, 28(1), 97-102. http://dx.doi.org/10.7211/jjsrt.28.97

Clark, C., Adriaens, P., \& Talbot, F. B. (2008). Green roof valuation: a probabilistic economic analysis of environmental benefits. Environ. Sci. Tech., 42(6), 2155-2161. http://dx.doi.org/10.1021/es0706652

Coffman, R. R., \& Waite, T. (2010). Vegetated roofs as reconciled habitats: Rapid assays beyond mere species counts. Urban Habitats 6(1). http://urbanhabitats.org/v06n01/vegetatedroofs_full.html

Colla, S. R., Willis, E., \& Packer, L. (2009). Can green roofs provide habitat for urban bees (Hymenoptera: Apidae)? Cities and the Environment, 2(1), 4. http://digitalcommons.lmu.edu/cgi/viewcontent.cgi?article= $1017 \&$ context $=$ cate

Collier, N., Mackay, D. A., Benkendorff, K., Austin, A. D., \& Carthew, S. M. (2006). Butterfly communities in South Australian urban reserves: estimating abundance and diversity using the Pollard walk. Austral Ecology, 31(2), 282-290. http://dx.doi.org/10.1111/j.1442-9993.2006.01577.x

Collinge, S. K., Prudic, K. L., \& Oliver, J. C. (2003). Effects of local habitat characteristics and landscape context on grassland butterfly diversity. Conservation Biology, 17(1), 178-187. http://dx.doi.org/10.1046/j. 1523-1739.2003.01315.x

Davies, R., Simcock, R., \& Toft, R., (2010). Islands in the sky, urban biodiversity enhancement in NZ on indigenous living roof landscapes. 44th Annual Conference of the Architectural Science Association, ANZAScA 2010, Unitec Institute of Technology.

Dennis, R. L., \& Hardy, P. B. (2001). Loss rates of butterfly species with urban development. A test of atlas data and sampling artefacts at a fine scale. Biodiversity \& Conservation, 10(11), 1831-1837. http://dx.doi.org/10. 1023/A:1013161522916

Di Mauro, D., Dietz, T., \& Rockwood, L. (2007). Determining the effect of urbanization on generalist butterfly species diversity in butterfly gardens. Urban ecosystems, 10(4), 427-439. http://dx.doi.org/10.1007/s1125 2-007-0039-2

Dramstad, W. E., Olson, J. D., \& Forman, R. T. T. (1996). Landscape Ecology Principles in Landscape Architecture and Land-use Planning. Harvard University Graduate School of Design.

Everaars, J., Strohbach, M. W., Gruber, B., \& Dormann, C. F. (2011). Microsite conditions dominate habitat selection of the red mason bee (Osmia bicornis, Hymenoptera: Megachilidae) in an urban environment: A case study from Leipzig, Germany. Landscape and Urban Planning, 103(1), 15-23. http://dx.doi.org/10. 1016/j.landurbplan.2011.05.008 
Feltwell, J. (1993). The illustrated encyclopedia of butterflies. Blandford a Cassell imprin, London.

Fernandez-Canero, R., \& Gonzalez-Redondo, P. (2010). Green roofs as a habitat for birds: a review. Journal of Animal and Veterinary Advances, 9(15), 2041-2052. http://dx.doi.org/10.3923/javaa.2010.2041.2052

Fish and Wildlife Service. (1981). Standards for the development of habitat suitability index models for use in the habitat evaluation procedures. U.S.D.I. Fish and Wildlife Service, Division of Ecological Services. ESM 103.

Gedge, D., \& Kadas, G. (2005). Green roofs and biodiversity. Biologist, 52(3), 161-169.

Hardy, P. B., \& Dennis, R. L. (1999). The impact of urban development on butterflies within a city region. Biodiversity \& Conservation, 8(9), 1261-1279. http://dx.doi.org/10.1023/A:1008984905413

Hiura, I. (1973). Butterfly across the sea. Aoki Shobo, Tokyo.

Jiang, S. L. (2012). Studies on the butterfly fauna and ecology of Biha Park in Taipei City. Master's thesis, University of Taipei.

Kadas, G. (2006). Rare invertebrates colonizing green roofs in London. Urban Habitats, 4(1), 66-86

Kadlec, T., Benes, J., Jarosik, V., \& Konvicka, M. (2008). Revisiting urban refuges: changes of butterfly and burnet fauna in Prague reserves over three decades. Landscape and Urban Planning, 85(1), 1-11. http://dx.doi.org/10.1016/j.landurbplan.2007.07.007

Ksiazek, K., Fant, J., \& Skogen, K. (2012). An assessment of pollen limitation on Chicago green roofs. Landscape and Urban Planning, 107(4), 401-408. http://dx.doi.org/10.1016/j.landurbplan.2012.07.008

Lin, C. J. (2008). Taiwan Butterfly host and nectar plant illustrated handbook. Commonwealth Publishing Co., Ltd, Taipei City, Taiwan, ROC.

Lundholm, J. T. (2006). Green roofs and facades: a habitat template approach. Urban habitats, 4(1). http://www.urbanhabitats.org/v04n01/habitat_full.html

MacIvor, J. S., \& Lundholm, J. (2011). Insect species composition and diversity on intensive green roofs and adjacent level-ground habitats. Urban Ecosystems, 14(2), 225-241. http://dx.doi.org/10.1007/s11252010-0149-0

Madre, F., Vergnes, A., Machon, N., \& Clergeau, P. A. (2013). Comparison of 3 types of green roof as habitats for arthropods. Ecological Engineering, 57, 109-117. http://dx.doi.org/10.1016/j.ecoleng.2013.04.029

Maes, D., \& Bonte, D. (2006). Using distribution patterns of five threatened invertebrates in a highly fragmented dune landscape to develop a multispecies conservation approach. Biological Conservation, 133(4), 490-499. http://dx.doi.org/10.1016/j.biocon.2006.08.001

Matteson, K. C., \& Langellotto, G. A. (2010). Determinates of inner city butterfly and bee species richness. Urban Ecosystems, 13(3), 333-347. http://dx.doi.org/10.1007/s11252-010-0122-y

Molles, M. C. (2005). Ecology: concepts and applications. McGraw-Hill, New York

Oberndorfer, E., Lundholm, J., Bass, B., Coffman, R. R., Doshi, H., Dunnett, N., ... Rowe, B. (2007). Green roofs as urban ecosystems: ecological structures, functions, and services. BioScience, 57(10), 823-833. http://dx.doi.org/10.1641/B571005

Saarinen, K., Valtonen, A., Jantunen, J., \& Saarnio, S. (2005). Butterflies and diurnal moths along road verges: does road type affect diversity and abundance? Biological Conservation, 123(3), 403-412. http://dx.doi.org/10.1016/j.biocon.2004.12.012

Schamberger, M. L., \& O'Neil, L. J. (1986). Concepts and constraints of habitat-model testing. In: Vemer J, Momson ML, Ralph CJ (eds) Wildlife 2000. The University of Wisconsin Press, Madison, Wisconsin, pp 177-182.

Schindler, B. Y., Griffith, A. B., \& Jones, K. N. (2011). Factors influencing arthropod diversity on green roofs. Cities and the Environment, 4(1). Retrieved from http://digitalcommons.lmu.edu/cgi/viewcontent.cgi? article $=1085 \&$ context $=$ cate.

Schrader, S., \& Böning, M. (2006). Soil formation on green roofs and its contribution to urban biodiversity with emphasis on Collembolans. Pedobiologia, 50(4), 347-356. http://dx.doi.org/10.1016/j.pedobi.2006.06.003

Sharp, M. A., Parks, D. R., \& Ehrlich, P. R. (1974). Plant resources and butterfly habitat selection. Ecology, 55, 870-875. http://dx.doi.org/10.2307/1934423 
Smallidge, P. J., \& Leopold, D. J. (1997) .Vegetation management for the maintenance and conservation of butterfly habitats in temperate human-dominated landscapes. Landscape and Urban Planning, 38(3), 259-280. http://dx.doi.org/10.1016/S0169-2046(97)00038-8

Snep, R. P., WallisDeVries, M. F., \& Opdam, P. (2011). Conservation where people work: A role for business districts and industrial areas in enhancing endangered butterfly populations? Landscape and Urban Planning, 103(1), 94-101. http://dx.doi.org/10.1016/j.landurbplan.2011.07.002

TaiBNET. (2011). Catalogue of life in Taiwan. Biodiversity Research Center, Academia Sinica, Taiwan. Retrieved from http://taibnet.sinica.edu.tw/home.php

Taiwan Biodiversity Information Facility (TAIBIF). (2014). The Catalogue of Life of Taiwan Biodiversity. Academia Sinica, Taiwan, ROC. Retrieved from http://www.taibif.tw/en/catalogue_of_life/browse.

Taipei City Government. (2013, 2014). Taipei city statistical yearbook 2012, 2013. Taipei City Government, ROC.

Tonietto, R., Fant, J., Ascher, J., Ellis, K., \& Larkin, D. (2011). A comparison of bee communities of Chicago green roofs, parks and prairies. Landscape and Urban Planning, 103(1), 102-108. http://dx.doi.org/10.1016/j.landurbplan.2011.07.004

US General Services Administration (USGSA). (2014). The benefits and challenges of green roofs on public and commercial buildings: A report of the United States General Services Administration. ARUP Study. Washington: General Services Administration; 2013. Retrieved from http://www.gsa.gov/portal/getMedia Data?mediaId $=158783$

Vickery, M. L. (1995). Gardens: the neglected habitat. In: Pullin A (ed) Ecology and Conservation of Butterflies. Springer Netherlands, pp 123-134. http://dx.doi.org/10.1007/978-94-011-1282-6_9

Wood, B. C., \& Pullin, A. S. (2002). Persistence of species in a fragmented urban landscape: the importance of dispersal ability and habitat availability for grassland butterflies. Biodiversity \& Conservation, 11(8), 1451-1468. http://dx.doi.org/10.1023/A:1016223907962

Wood, P. A., \& Samways, M. J. (1991). Landscape element pattern and continuity of butterfly flight paths in an ecologically landscaped botanic garden, Natal, South Africa. Biological Conservation, 58(2), 149-166. http://dx.doi.org/10.1016/0006-3207(91)90117-R

Xue, C. X. (2003). Taiwan flowers and plants illustrated handbook. Taiwan: Pu-Lu Publishing Co., Ltd.

Zhou, M. Y. (2009). Studies on the chane of butterfly fauna at Daan Park in Taipei City. Ms thesis, University of Taipei. Master's thesis, University of Taipei.

\section{Copyrights}

Copyright for this article is retained by the author(s), with first publication rights granted to the journal.

This is an open-access article distributed under the terms and conditions of the Creative Commons Attribution license (http://creativecommons.org/licenses/by/3.0/). 